\section{Prostaglandin $I_{2}$ Is Not a Major Metabolite of Arachidonic Acid in Cultured Endothelial Cells from Human Foreskin Microvessels}

Israel F. Charo, Steven Shak, Marvin A. Karasek, Pamela M. Davison, and Ira M. Goldotein

Rosalind Russell Arthritis Research Laboratory, Department of Medicine, University of California, Medical Service, San

Francisco General Hospital, San Francisco, California 94110, and Department of Dermatology, Stanford University Medical Center, Stanford, California 94305 bstract. Prostaglandin $\mathrm{I}_{2}\left(\mathrm{PGI}_{2}\right)$, a potent vasodilator and inhibitor of platelet aggregation, is a major product of arachidonic acid metabolism in endothelial cells that are derived from large blood vessels (e.g., umbilical veins). We have examined whether $\mathrm{PGI}_{2}$ is also a major product of arachidonic acid metabolism in cultured endothelial cells that are derived from dermal microvessels in human newborn foreskin. Supernatants from confluent monolayers of endothelial cells that had been incubated for $20 \mathrm{~min}$ with $\left[{ }^{3} \mathrm{H}\right.$ ]arachidonic acid and the calcium ionophore A23187 $(10 \mu \mathrm{M})$ were assayed for prostaglandin $\mathrm{F}_{2 \alpha}\left(\mathrm{PGF}_{2 \alpha}\right)$, prostaglandin $\mathrm{E}_{2}\left(\mathrm{PGE}_{2}\right)$, and 6-keto-prostaglandin $\mathrm{F}_{1 \alpha}\left(\mathrm{PGF}_{1 \alpha}\right)$ (the stable metabolite of $\mathrm{PGI}_{2}$ ) by using authentic standards and high performance liquid chromatography. Whereas supernates from stimulated umbilical vein endothelial cells contained 6-keto-PGF $\mathrm{PG}_{1 \alpha} \geqslant \mathrm{PGF}_{2 \alpha} \gg \mathrm{PGE}_{2}$, supernates from stimulated foreskin microvessel endothelial cells contained $\mathrm{PGF}_{2 \alpha} \cong \mathrm{PGE}_{2} \gg 6-$ keto-PGF $_{1 \alpha}$. Similar results were obtained when supernates from stimulated, unlabeled endothelial cells were analyzed by radioimmunoassay. These data indicate that $\mathrm{PGI}_{2}$ is not a major metabolite of arachidonic acid in cultured endothelial cells from human foreskin microvessels.

Portions of this work were presented at the Annual Meeting of The American Society for Clinical Investigation, Washington, DC, 7 May 1984 and published in abstract form (1984. Clin. Res. 32:495A).

Address correspondence to Dr. Charo, San Francisco General Hospital.

Received for publication 13 April 1984.

J. Clin. Invest.

(c) The American Society for Clinical Investigation, Inc. 0021-9738/84/09/0914/06 $\$ 1.00$

Volume 74, September 1984, 914-919

\section{Introduction}

Endothelial cells, which line the walls of both large and small blood vessels, normally present a nonthrombogenic surface to circulating blood. Prostaglandin $\mathrm{I}_{2}\left(\mathrm{PGI}_{2}\right)^{1}$ is a major product of arachidonic acid metabolism in endothelial cells that are derived from large blood vessels (e.g., human umbilical veins) $(1,2)$. $\mathrm{PGI}_{2}$ may play a role in preventing thrombus formation by inhibiting both platelet aggregation $(1,2)$ and attachment of platelets to endothelial surfaces (3). Since microvascular endothelial cells differ from large vessel endothelial cells with respect to their morphology, growth characteristics, and ability to activate prothrombin in vitro (4-6), we have examined whether $\mathrm{PGI}_{2}$ is also a major product of arachidonic acid metabolism in these cells. We have found that cultured endothelial cells derived from dermal microvessels in human foreskin synthesize almost no $\mathbf{P G I}_{2}$. Instead, the major products of arachidonic acid metabolism in these microvascular endothelial cells are prostaglandins $F_{2 \alpha}$ and $E_{2}\left(\mathrm{PGF}_{2 \alpha}\right.$ and $\left.\mathrm{PGE}_{2}\right)$.

\section{Methods}

Endothelial cell cultures. Calcium- and magnesium-free Hanks' balanced salt solution (CMF-Hanks), Medium 199, Iscove's medium, fetal calf serum, $N$-2-hydroxyethylpiperazine- $N^{\prime}$-2-ethane sulfonic acid (Hepes buffer), penicillin, streptomycin, and trypsin were obtained from Gibco Laboratories, Grand Island, NY. Endothelial cells from freshly obtained human umbilical veins were isolated and cultured by using minor modifications of the methods described previously by Jaffe et al. (7). Cells were detached by incubating umbilical veins for $45 \mathrm{~min}$ with sterile CMF-Hanks, pH 7.4, that contained $3.0 \mathrm{mg} / \mathrm{ml}$ trypsin and 1.0 $\mathrm{mg} / \mathrm{ml}$ ethylenediaminetetraacetate (EDTA) (Sigma Chemical Co., St.

1. Abbreviations used in this paper: CMF-Hanks, calcium- and magnesium-free Hanks' balanced salt solution; FGF, fibroblast growth factor, HPLC, high performance liquid chromatography; PG, prostaglandin; $\mathrm{PGE}_{2}, \mathrm{PGF}_{2 \alpha}$, and $\mathrm{PGI}_{2}$, prostaglandins $\mathrm{E}_{2}, \mathrm{~F}_{2 \alpha}$, and $\mathrm{I}_{2}$, respectively. 
Louis, MO). Incubation with trypsin yielded as many viable endothelial cells as incubation with collagenase and was considerably less costly. Detached endothelial cells were sedimented at $250 \mathrm{~g}$ for $10 \mathrm{~min}$, washed once, and resuspended in Medium 199, supplemented with $20 \%$ (vol/vol) fetal calf serum, $25 \mathrm{mM}$ Hepes buffer, pH 7.4, 100 $\mathrm{U} / \mathrm{ml}$ penicillin, $100 \mu \mathrm{g} / \mathrm{ml}$ streptomycin, and $100 \mathrm{ng} / \mathrm{ml}$ fibroblast growth factor (FGF) (generously provided by Dr. Denis Gospodarowicz, University of California, San Francisco). Primary cultures were established in 35-mm diam plastic Petri dishes (Falcon Plastics, Oxnard, CA) that had been coated previously with fibronectin $(0.05 \mathrm{mg} /$ dish $)$, which was prepared from plasma by the method of Engvall and Ruoslahti (8). Plating density was $\sim 2.5 \times 10^{5}$ cells/dish. Primary cultures were provided with fresh medium every $48 \mathrm{~h}$, and grown to confluence at $37^{\circ} \mathrm{C}$ in an environment of $5 \% \mathrm{CO}_{2}$ and $100 \%$ humidity (usually 3-5 d). For subculture, cells were harvested by brief treatment (4 min, $37^{\circ} \mathrm{C}$ ) with EDTA $(0.2 \mathrm{mg} / \mathrm{ml})$-trypsin $(0.5 \mathrm{mg} / \mathrm{ml})$ in CMFHanks, sedimented, washed once, resuspended in fresh medium, and diluted 1:4 before plating $\left(\sim 2.5 \times 10^{5}\right.$ cells/dish).

Endothelial cells from the microvessels of newborn human foreskin were isolated as described by Davison et al. (4). Foreskin tissue, obtained after routine circumcision, was collected in sterile $150 \mathrm{mM}$ $\mathrm{NaCl}$ that contained $400 \mathrm{U} / \mathrm{ml}$ penicillin and $200 \mu \mathrm{g} / \mathrm{ml}$ streptomycin. The epidermis was removed with a Castroviejo keratome (Storz Instrument Co., St. Louis, MO), and the highly vascular region of the dermis was sectioned into 5-mm cubes. These were incubated for 45 min at $37^{\circ} \mathrm{C}$ with $3.0 \mathrm{mg} / \mathrm{ml}$ trypsin in sterile $150 \mathrm{mM} \mathrm{NaCl}$ (supplemented with $1.0 \mathrm{mg} / \mathrm{ml}$ glucose, $10 \mathrm{mg} / \mathrm{ml} \mathrm{EDTA}$, and $0.4 \mathrm{mg} /$ $\mathrm{ml} \mathrm{KCl}$, and adjusted to $\mathrm{pH}$ 7.3). After washing the tissue sections three times with $150 \mathrm{mM} \mathrm{NaCl}$, endothelial cells were expressed from small blood vessels into modified Iscove's medium (9) that contained $10 \%$ (vol/vol) human (maternal) serum and antibiotics. Cells were pooled, sedimented ( $800 \mathrm{~g}$ for $1 \mathrm{~min}$ ), and resuspended in modified Iscove's medium supplemented with $10 \%$ (vol/vol) human (maternal) serum, antibiotics, and $0.5 \mathrm{mM}$ dibutyryl cyclic 3',5'-adenosine monophosphate (cAMP) (Sigma Chemical Co.) before plating onto 35-mm diam culture dishes that had been coated previously with fibronectin $(0.05 \mathrm{mg} /$ dish) (4). Because of the relatively small yield of microvessel endothelial cells, plating density for primary cultures was $\sim 3 \times 10^{4}$ cells/dish. Primary cultures were provided with fresh medium every $72 \mathrm{~h}$ and maintained at $37^{\circ} \mathrm{C}\left(6 \% \mathrm{CO}_{2}, 100 \%\right.$ humidity) until they were confluent ( 5-7 d). Modified Iscove's medium containing $10 \%$ (vol/vol) maternal serum was as effective as the medium reported previously (i.e., minimal essential medium that contained $50 \%$ (vol/ vol) pooled human serum) (4) for supporting growth of the microvascular endothelial cells. For subculture, cells were harvested with EDTAtrypsin (see above), sedimented, washed once, resuspended in fresh medium, and diluted 1:4 before plating $\left(\sim 2.0 \times 10^{5}\right.$ cells/dish). Only confluent monolayers of either primary or early-passage endothelial cells (5-7 d after isolation or passage) were used in the experiments described below.

By using only the highly vascular region of the dermis as a source of microvessel endothelial cells, contamination of primary cultures with either fibroblasts or keratinocytes (easily recognized by their characteristic morphology) was minimal. Substantially longer and more vigorous treatment of dermal tissue with trypsin is required to release fibroblasts. Furthermore, proliferation of fibroblasts in primary cultures is inhibited in medium that contains CAMP (10). When contamination was observed in primary cultures, microvessel endothelial cells were separated from fibroblasts and keratinocytes by brief treatment with EDTA-trypsin and replated. Only confluent cultures containing cells that exhibited a homogeneous cobblestone morphology were used in the experiments described below (Fig. 1). In representative cultures, $>95 \%$ of the umbilical vein and dermal microvessel endothelial cells stained positively for Factor VIII antigen by indirect immunofluorescence (4) (Fig. 2) and also contained characteristic Weibel-Palade bodies (11) when examined by transmission electron microscopy (not shown).

Incubations with $\left[{ }^{3} \mathrm{H}\right]$ arachidonic acid. Confluent monolayers of umbilical vein and foreskin microvessel endothelial cells were incubated for $2 \mathrm{~h}$ in fresh medium without FGF or cAMP, and washed before

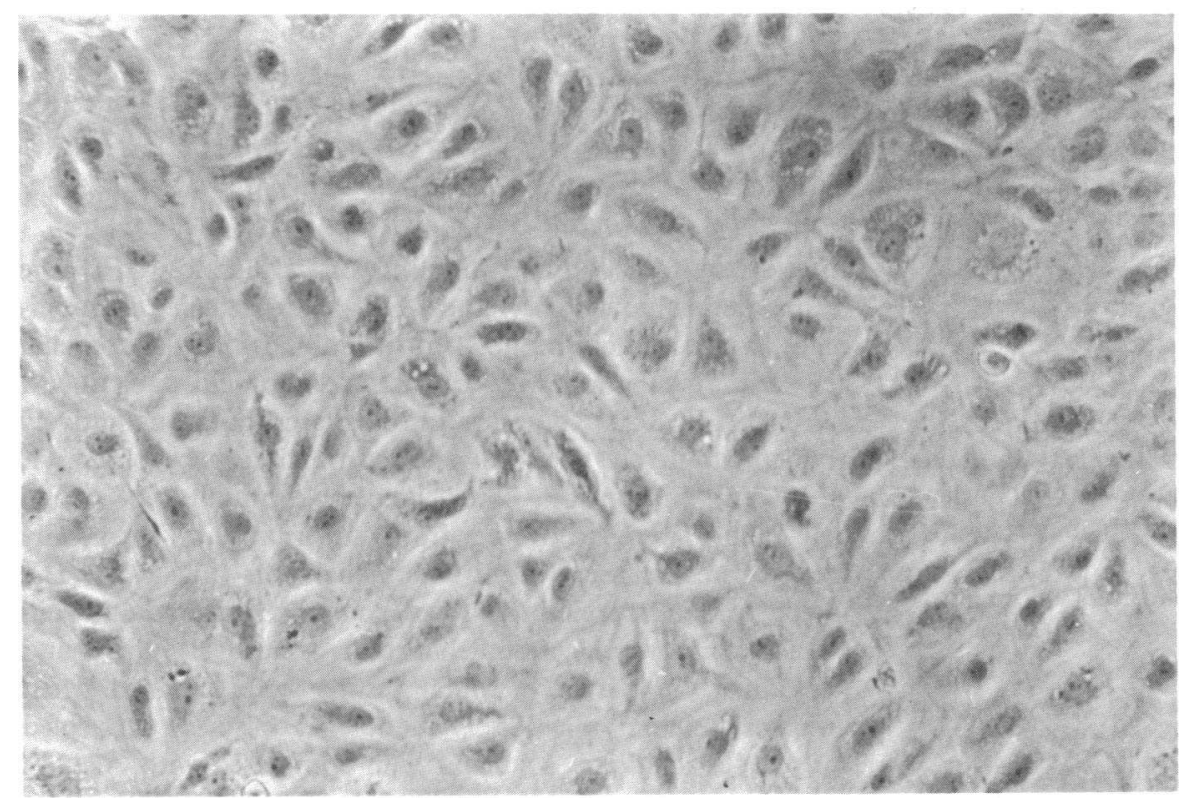

Figure 1. Morphology of cultured microvessel endothelial cells at confluence (phase microscopy). $\times 300$. 


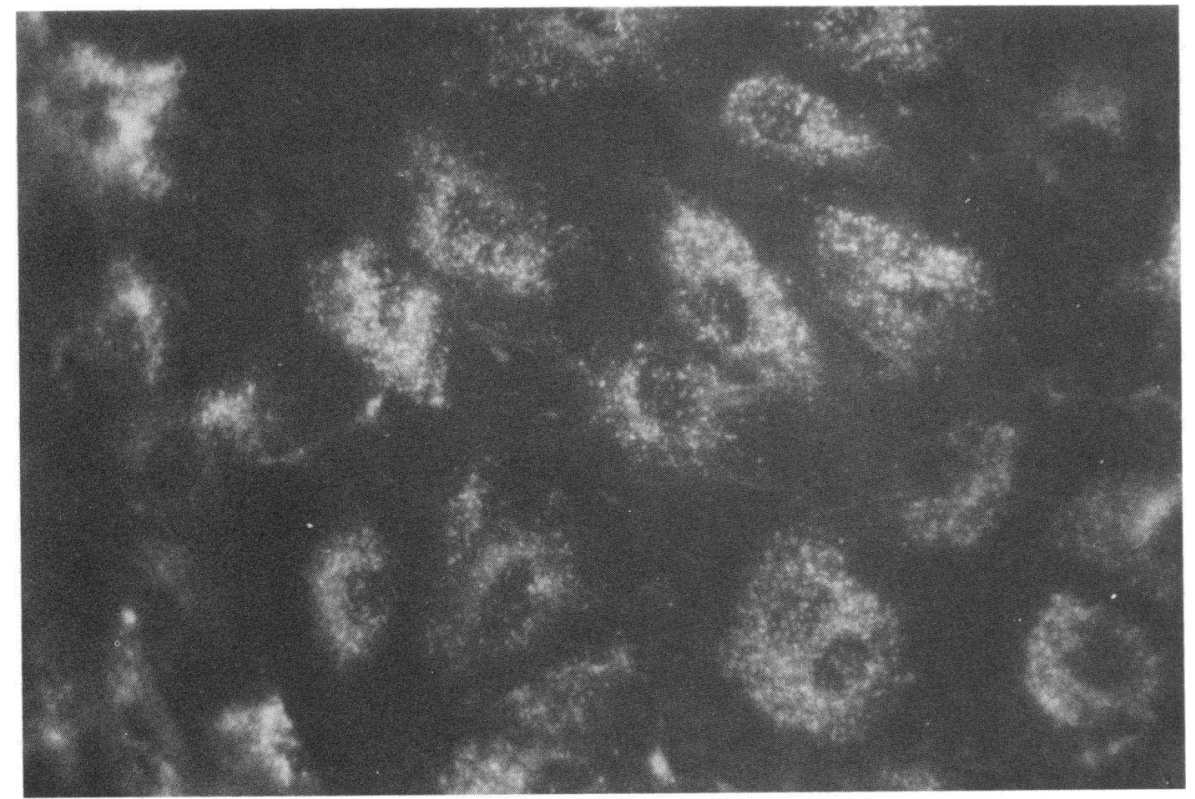

Figure 2. Indirect immunofluorescent staining for Factor VIII antigen in primary culture of foreskin microvessel endothelial cells $\times 1,300$.

incubation for $20 \mathrm{~min}$ at $37^{\circ} \mathrm{C}$ in serum-free medium that contained ${ }^{3} \mathrm{H}$ ]arachidonic acid $\left(1.0 \mu \mathrm{Ci} / 10^{6} \mathrm{cells}\right)(87.4 \mathrm{Ci} / \mathrm{mmol})$ (New England Nuclear, Boston, MA) and the calcium ionophore A23187 (10 $\mu \mathrm{M})$ (Sigma Chemical Co.). In some experiments, endothelial cells were prelabeled by incubation for $20 \mathrm{~h}$ with $\left[{ }^{3} \mathrm{H}\right]$ arachidonic acid $(0.5 \mu \mathrm{Ci} /$ $10^{6}$ cells) before exposure to A23187. No changes in endothelial cell morphology or viability (trypan blue exclusion) were observed after prelabeling.

Supernates from quadruplicate culture dishes were pooled, extracted with ice-cold acetone $(1 \mathrm{vol})$ and petroleum ether $(3 \mathrm{vol})$ (Burdick \& Jackson Laboratories, Muskegon, MI), acidified to pH 3.0 with $1.0 \mathrm{~N}$ $\mathrm{HCl}$, and then extracted twice with ethyl acetate (1 vol) (Burdick \& Jackson Laboratories) (12). The ethyl acetate phases were combined and evaporated to dryness under vacuum. Extracted material was dissolved in acetonitrile (Burdick \& Jackson Laboratories)/water/acetic acid (Sigma Chemical Co.) (65:35:1). Recoveries of radiolabeled (tritiated) PG standards (New England Nuclear) using this extraction procedure were $>90 \%$.

High performance liquid chromatography (HPLC). Reverse-phase HPLC was performed by using an Ultrasphere-ODS C18 column (5 $\mu \mathrm{M}, 4.7 \mathrm{~mm} \times 25 \mathrm{~cm})$ and precolumn $(4.7 \mathrm{~mm} \times 3 \mathrm{~cm})$ (Rainin Instrument Co., Emeryville, CA). Lipids were eluted isocratically at a flow rate of $1.0 \mathrm{ml} / \mathrm{min}$ with acetonitrile/water/acetic acid (65:35:1). HPLC fractions $(1.0 \mathrm{ml})$ were analyzed for radioactivity by liquid scintillation counting after mixing with $10 \mathrm{ml}$ Aquasol 2 (New England Nuclear). In experiments performed to calibrate the column, recoveries of tritiated PG standards were $>95 \%$.

Radioimmunoassays (RIA). Confluent monolayers of umbilical vein and foreskin microvessel endothelial cells $\left(8-9 \times 10^{5}\right.$ and 7-8 $\times 10^{5}$ per dish, respectively) were preincubated for $10 \mathrm{~min}$ with and without $10 \mu \mathrm{M}$ indomethacin (Sigmal Chemical Co.) before exposure for $20 \mathrm{~min}$ to either A23187 (10 $\mu \mathrm{M})$, human $\alpha$-thrombin $(5.0 \mathrm{U} / \mathrm{ml})$ (provided by Dr. J. W. Fenton, II, Dept. of Health, Albany, NY), or unlabeled arachidonic acid $(10 \mu \mathrm{M})$ (Nu-Chek Prep, Inc., Elysian, $\mathrm{MN}$ ). Supernates were assayed for 6-keto-PGF $1 \alpha, \mathrm{PGF}_{2 \alpha}$, and $\mathrm{PGE}_{2}$ by RIA as described previously (13), by using antisera from Seragen Inc., Boston, MA, and tritiated PG standards. There was $>35 \%$ binding of radiolabeled antigen in all assays, and the lower limit of detection was $50 \mathrm{pg}(0.5 \mathrm{ng} / \mathrm{ml})$. Total cell DNA was measured by the method of Labarca and Paigen (14).

In some experiments, culture supernates were extracted and subjected to HPLC before RIA. RIA was performed on aliquots of 1.0-ml HPLC fractions diluted 1:5 with $0.05 \mathrm{M}$ Tris buffer, $\mathrm{pH}$ 7.4. Authentic, unlabeled PG standards (Upjohn Co., Kalamazoo, MI) were dissolved in the HPLC mobile phase and included in the usual standard curves to control for possible effects of the solvents on the RIA.

\section{Results}

\section{Products of exogenous arachidonic acid formed by endothelial cells}

Analysis by HPLC. Large amounts of $\left[{ }^{3} \mathrm{H}\right] 6-$ keto-PGF $_{1 \alpha}$ (the stable metabolite of $\mathrm{PGI}_{2}$ ) and $\mathrm{PGF}_{2 \alpha}$ were detected in supernates from confluent monolayers of umbilical vein endothelial cells after incubation with $\left[{ }^{3} \mathrm{H}\right]$ arachidonic acid and $10 \mu \mathrm{M}$ A23187 (Fig. $3 \mathrm{~A}$ ). These results are similar both qualitatively and quantitatively to those reported previously by others (1, $2,15,16)$. In contrast, barely detectable amounts of $\left[{ }^{3} \mathrm{H}\right] 6-$ keto-PGF ${ }_{1 \alpha}$ were recovered from supernates of identically treated foreskin microvessel endothelial cells (Fig. $3 \mathrm{~B}$ ). The major products formed from exogenous $\left[{ }^{3} \mathrm{H}\right]$ arachidonic acid by the microvessel endothelial cells were $\left[{ }^{3} \mathrm{H}\right] \mathrm{PGF}_{2 \alpha}$ and $\left.{ }^{3} \mathrm{H}\right] \mathrm{PGE}_{2}$. Qualitatively similar results were obtained when umbilical vein and microvessel endothelial cells were prelabeled with $\left[{ }^{3} \mathrm{H}\right]$ arachidonic acid and then stimulated with A23187 (not shown). In control experiments, $>95 \%$ of $\left[{ }^{3} \mathrm{H}\right] 6-$ ketoPGF $_{1 \alpha}$ added to confluent monolayers of microvessel endothelial 


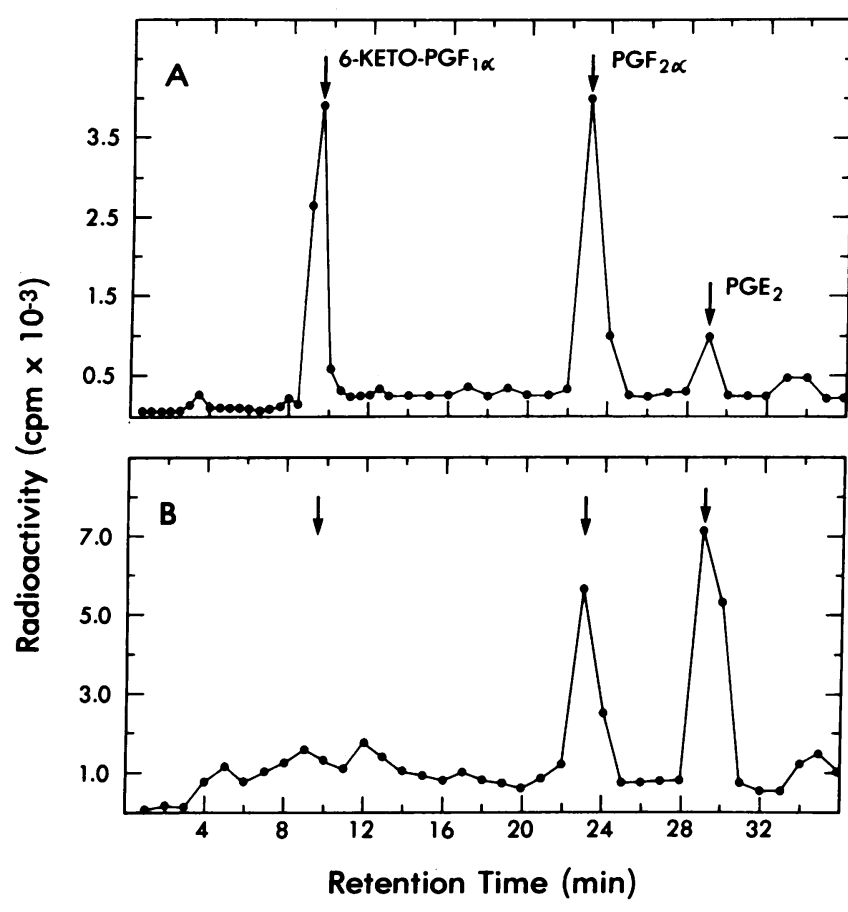

Figure 3. Products formed by endothelial cells from exogenous arachidonic acid. Confluent monolayers of $1.0 \times 10^{5}$ human umbilical vein endothelial cells $(A)$ and $1.0 \times 10^{6}$ human foreskin microvessel endothelial cells $(B)$ were incubated for $20 \mathrm{~min}$ at $37^{\circ} \mathrm{C}$ with $\left[{ }^{3} \mathrm{H}\right]$ arachidonic acid $\left(1.0 \mu \mathrm{Ci} / 10^{6}\right.$ cells) and the calcium ionophore A23187 $(10 \mu \mathrm{M})$. Supernates were extracted and analyzed by HPLC as described in Methods. Arrows indicate retention times of authentic standards (6-keto-PGF $1 \alpha, 9.4 \mathrm{~min}$ PGF $_{2 \alpha}, 23.0 \mathrm{~min}$; and $\mathrm{PGE}_{2}, 29.0$ $\mathrm{min})$. Data shown are from a representative experiment $(n=5)$.

cells was recovered intact after incubation for $20 \mathrm{~min}$ with or without A23187. Thus, our inability to detect 6-keto-PGF ${ }_{1 \alpha}$ in supernates from stimulated microvessel endothelial cells most likely was due to failure of these cells to synthesize this compound, and not simply due to either binding or catabolism of 6-keto-PGF ${ }_{1 \alpha}$ by the endothelial cells.

Analysis by RIA. Supernates from confluent monolayers of umbilical vein endothelial cells that had been incubated for 20 min with either A23187, $\alpha$-thrombin, or arachidonic acid contained 6-keto-PGF $\mathrm{PG}_{1 \alpha} \cong \mathrm{PGF}_{2 \alpha} \gg \mathrm{PGE}_{2}$ (measured by RIA) (Table I). Identical results were obtained with umbilical vein endothelial cells that had been grown in Iscove's medium that contained human serum and cAMP (not shown). In contrast, only very small amounts of 6-keto-PGF $F_{1 \alpha}$ were detected by RIA in supernates from similarly treated foreskin microvessel endothelial cells. Rather, $\mathrm{PGF}_{2 \alpha}$ and $\mathrm{PGE}_{2}$ were the major products of arachidonic acid metabolism in these stimulated cells. In response to $A 23187$, for example, microvessel endothelial cells generated approximately the same amount of $\mathrm{PGE}_{2}$ as umbilical vein endothelial cells, but less than $1 / 1$ th as much 6-keto-PGF - $_{1 \alpha}$. Levels of 6-keto-PGF $1 \alpha, \mathrm{PGE}_{2}$, and $\mathrm{PGF}_{2 \alpha}$ were undetectable $(<0.5 \mathrm{ng} / \mathrm{ml})$ in supernates from both umbilical vein and microvessel endothelial cells that had been stimulated in the presence of $10 \mu \mathrm{M}$ indomethacin (not shown).

To confirm the specificity of the RIA and to increase the likelihood of detecting synthesis of 6-keto-PGF 1 $_{1 \alpha}$, supernates from stimulated microvessel endothelial cells were analyzed by RIA after extraction and HPLC. None of the HPLC fractions at or near the retention time of authentic 6-keto$\mathrm{PGF}_{1 \alpha}$ contained detectable amounts of this arachidonic acid metabolite (Fig. 4). Again, the major products detected were $\mathrm{PGF}_{2 \alpha}$ and $\mathrm{PGE}_{2}$.

\section{Discussion}

Results of our studies indicate that, unlike endothelial cells derived from large blood vessels, human foreskin microvessel endothelial cells synthesize little, if any, $\mathbf{P G I}_{2}$ in vitro. Whereas umbilical vein endothelial cells synthesized abundant amounts

Table I. Products of Arachidonic Acid Metabolism by Endothelial Cells: Analysis by RIA

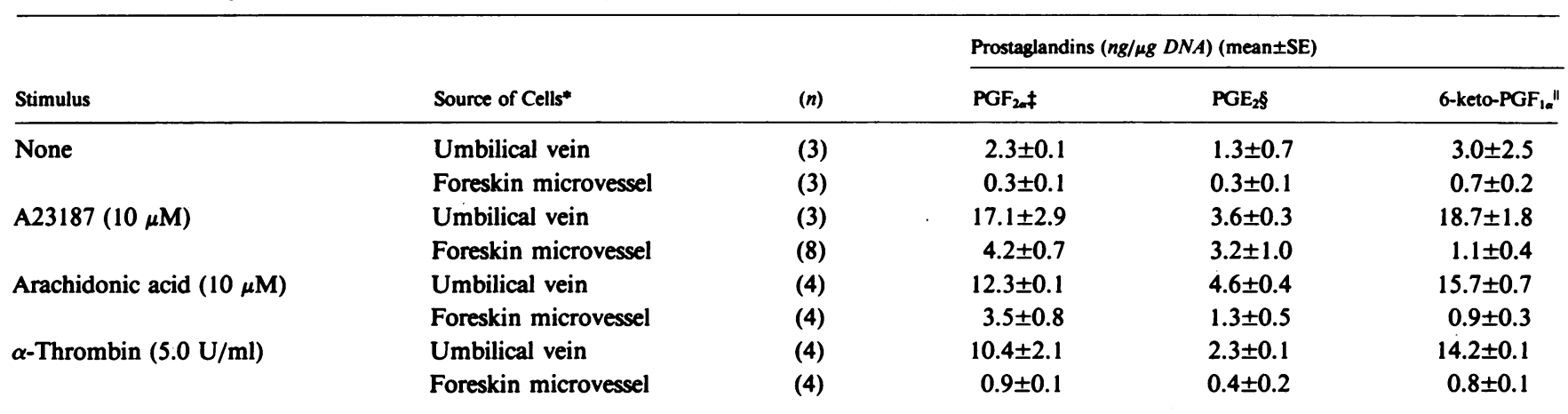

* Confluent monolayers of umbilical vein and dermal microvessel endothelial cells (8-9 $\times 10^{5}$ and 7-8 $\times 10^{5}$ per dish, respectively) were incubated with or without stimuli for $20 \mathrm{~min}$ at $37^{\circ} \mathrm{C}$ in serum-free media. $¥$ The antiserum to $\mathrm{PGF}_{2 \alpha}$ cross-reacted with 6-keto-PGF ${ }_{1 \alpha}(0.5 \%)$, $\mathrm{PGE}_{2}(1.1 \%)$, 6-keto-PGE 1 (0.1\%), and thromboxane $\mathrm{B}_{2}(0.3 \%)$. § The antiserum to $\mathrm{PGE}_{2}$ cross-reacted with 6-keto-PGF $\mathrm{P}_{1 \alpha}(1.0), \mathrm{PGF}_{2 \alpha}$ $(<1.0 \%)$, 6-keto-PGE $1 \alpha(1.3 \%)$, and thromboxane $\mathrm{B}_{2}(<0.1 \%)$. " The antiserum to 6-keto-PGF $1 \alpha$ cross-reacted with PGE $2(0.6 \%), \mathrm{PGF}_{2 \alpha}(2.2 \%)$, 6-keto-PGE $1 \alpha(6.8 \%)$, and thromboxane $B_{2}(<0.1 \%)$. 


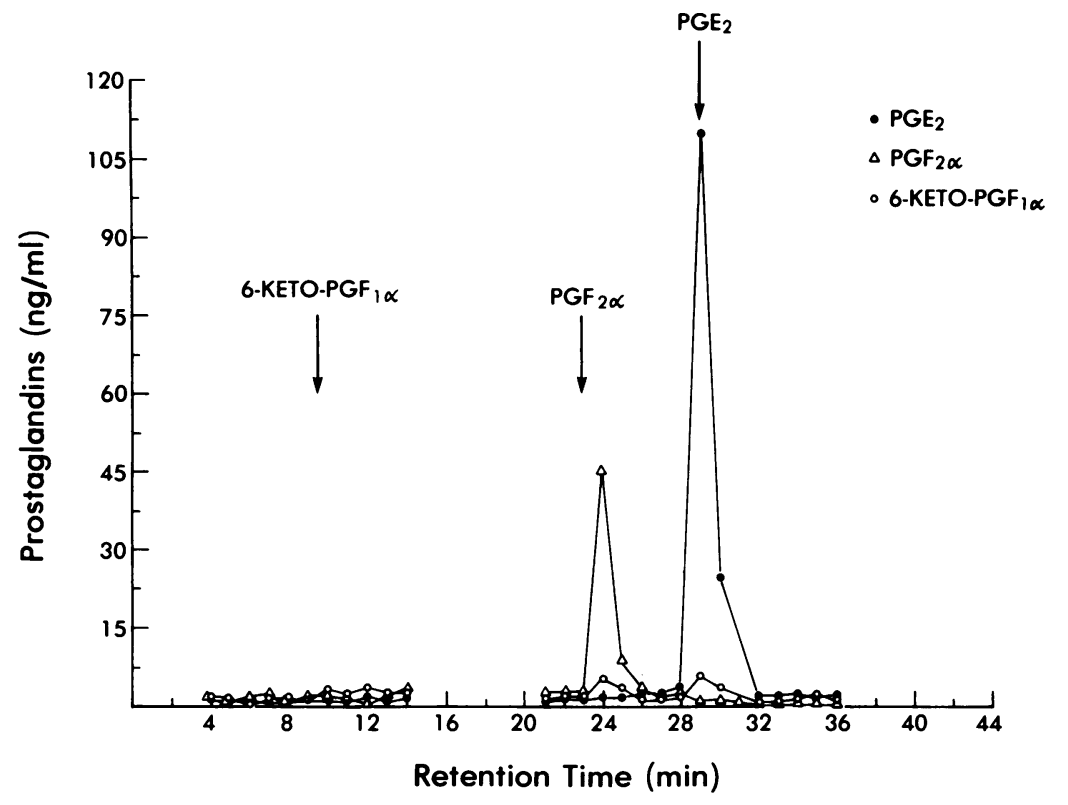

Figure 4. Arachidonic acid metabolism by microvessel endothelial cells: analysis of HPLC fractions by RIA. A confluent monolayer $\left(6 \times 10^{6}\right.$ cells) of microvessel endothelial cells was incubated for 20 $\min$ at $37^{\circ} \mathrm{C}$ with $10 \mu \mathrm{M}$ A23187. The supernate was then extracted and subjected to HPLC. RIA was performed on individual $(1.0 \mathrm{ml}) \mathrm{HPLC}$ fractions for 6-keto-PGF ${ }_{1 \alpha}(0), \mathrm{PGF}_{2 \alpha}(\Delta)$, and $\mathrm{PGE}_{2}$ (๑). Analysis of the same culture supernate before HPLC confirmed that the ratio of $\mathrm{PGE}_{2}$ to $\mathrm{PGF}_{2 a}$ was 2.2:1. of $\left[{ }^{3} \mathrm{H}\right]$ 6-keto-PGF $F_{1 \alpha}$ and $\left[{ }^{3} \mathrm{H}\right] \mathrm{PGF}_{2 \alpha}$ when incubated with $\left[{ }^{3} \mathrm{H}\right]$ arachidonic acid and the calcium ionophore A23187, identically treated foreskin microvessel endothelial cells synthesized only $\left[{ }^{3} \mathrm{H}\right] \mathrm{PGF}_{2 \alpha}$ and $\left[{ }^{3} \mathrm{H}\right] \mathrm{PGE}_{2}$ (Fig. 3). Similar results were obtained when supernates from confluent monolayers of endothelial cells were analyzed by RIA. Umbilical vein endothelial cells responded to A23187, $\alpha$-thrombin, and arachidonic acid by synthesizing immunoreactive 6-keto-PGF ${ }_{1 \alpha} \cong \mathrm{PGF}_{2 \alpha}$ $>\mathrm{PGE}_{2}$. Capillary endothelial cells, however, synthesized primarily $\mathrm{PGF}_{2 \alpha}$ and $\mathrm{PGE}_{2}$, and only after stimulation with A23187 and arachidonic acid (Table I). Microvessel endothelial cells apparently did not respond to $\alpha$-thrombin. Failure to detect significant amounts of 6-keto-PGF ${ }_{1 \alpha}$ in these supernates was not due to either binding or degradation of this arachidonic acid metabolite by the microvessel endothelial cells, and could not be attributed to effects of either the isolation procedure or the culture medium. Both types of endothelial cells were isolated by using trypsin and the medium used to culture the microvessel endothelial cells did not affect the metabolism of arachidonic acid by umbilical vein endothelial cells. Finally, to increase the likelihood of detecting synthesis of 6-keto$\mathrm{PGF}_{1 \alpha}$ by microvessel endothelial cells, supernates obtained after incubating these cells with A23187 were extracted, subjected to HPLC, and then analyzed by RIA. Although these procedures concentrated the $\mathrm{PGF}_{2 \alpha}$ and $\mathrm{PGE}_{2}$ in the original culture supernates approximately fourfold, none of the HPLC fractions at or near the retention time of authentic 6-ketoPGF $_{1 \alpha}$ contained measurable amounts of this arachidonic acid metabolite (Fig. 4). Furthermore, since the antiserum used to measure 6-keto-PGF - $_{1 \alpha}$ appeared to cross-react with $\mathrm{PGF}_{2 \alpha}$ and $\mathrm{PGE}_{2}$, it is likely that analyses of whole culture supernates by RIA (Table I) somewhat overestimated the amounts of 6-ketoPGF $_{1 \alpha}$ formed by foreskin microvessel endothelial cells.
Microvascular endothelial cells from experimental animals also synthesize less $\mathbf{P G I}_{2}$ than do large vessel endothelial cells. Gerritsen and Cheli (17), for example, reported that endothelial cells from rabbit coronary microvessels synthesize similar amounts of $\mathrm{PGE}_{2}$ and $\mathrm{PGF}_{2 \alpha}$, but considerably less 6-keto$\mathrm{PGF}_{1 \alpha}$, as compared with endothelial cells from rabbit aorta. Isolated capillaries from guinea pig and rat brain also synthesize much less 6-keto-PGF $F_{1 \alpha}$ than either $\mathrm{PGE}_{2}, \mathrm{PGF}_{2 \alpha}$, or prostaglandin $D_{2}$ (18). Finally, Coughlin et al. (19) detected only very small amounts of 6-keto-PGF ${ }_{1 \alpha}$ in supernates of stimulated bovine adrenal microvessel endothelial cells (as compared with bovine aortic endothelial cells).

Although it has been proposed (20) that synthesis of $\mathbf{P G I}_{2}$ by endothelial cells is crucial for preventing platelet adherence to blood vessel walls and platelet aggregation, this remains unproven. Indeed, recently summarized evidence (21) suggests that this may not be the case. Our findings that cultured microvessel endothelial cells have only a limited capacity to synthesize $\mathrm{PGI}_{2}$ suggest that this arachidonic acid metabolite may not play a critical role in regulating hemostasis in the microvasculature.

\section{Acknowledgments}

We thank Drs. J. W. Fenton, II, and D. J. Gospodarowicz for their generous gifts of human thrombin and fibroblast growth factor. We also wish to thank the delivery room nurses at the San Francisco General Hospital and the Seton Medical Center for their help in collecting umbilical cords.

This work was supported by grants from the National Institutes of Health (HL-28475, HL-19155, AI-14752, and AG-01312), the Treadwell Foundation, and the Arthritis Foundation. Dr. Shak was supported by a National Pulmonary Faculty Training Center Grant (HL-07159) from the National Institutes of Health. 


\section{References}

1. Weksler, B. B., A. J. Marcus, and E. A. Jaffe. 1977. Synthesis of prostaglandin $I_{2}$ (prostacyclin) by cultured human and bovine endothelial cells. Proc. Natl. Acad. Sci. USA. 74:3922-3926.

2. Marcus, A. J., B. B. Weksler, E. A. Jaffe, and M. J. Broekman. 1980. Synthesis of prostacyclin from platelet-derived endoperoxides by cultured human endothelial cells. J. Clin. Invest. 66:979-986.

3. Czervionke, R. L., J. B. Smith, G. L. Fry, J. C. Hoak, and D. L. Haycraft. 1979. Inhibition of prostacyclin by treatment of endothelium with aspirin. Correlation with platelet adherence. J. Clin. Invest. 63:1089-1092.

4. Davison, P. M., K. Bensch, and M. A. Karasek. 1980. Isolation and growth of endothelial cells from the microvessels of the newborn human foreskin in cell culture. J. Invest. Dermatol. 75:316-321.

5. Davison, P. M., and M. A. Karasek. 1981. Human dermal microvascular endothelial cells in vitro. Effect of cyclic AMP on cellular morphology and proliferation rate. J. Cell. Physiol. 106:253258.

6. Rodgers, G. M., and M. A. Shuman. 1983. Prothrombin is activated on vascular endothelial cells by factor $\mathrm{Xa}$ and calcium. Proc. Natl. Acad. Sci. USA. 80:7001-7005.

7. Jaffe, E. A., R. L. Nachman, C. G., Becker, and C. R. Minick. 1973. Culture of human endothelial cells derived from umbilical veins. Identification by morphologic and immunologic criteria. J. Clin. Invest. 52:2745-2756.

8. Engvall, E., and E. Ruoslahti. 1977. Binding of soluble form of fibroblast surface protein, fibronectin, to collagen. Int. J. Cancer 20:1-5.

9. Foung, S., S. Perkins, A. Raubitschek, J. Larrick, G. Lizak, D. Fishwild, E. G. Engleman, and F. C. Grumet. 1984. Rescue of human monoclonal antibody production from an EBV-transformed B cell line by fusion to a human-mouse hybridoma. J. Immunol. Methods 70:8390.

10. Pastan, I., and G. S. Johnson. 1974. Cyclic AMP and the transformation of fibroblasts. Adv. Cancer Res. 19:303-326.
11. Weibel, E. R., and G. E. Palade. 1964. New cytoplasmic components in arterial endothelium. J. Cell Biol. 23:101-112.

12. Green, K., M. Hamberg, B. Samuelsson, and J. C. Frolich. 1978. Extraction and chromatographic procedures for purification of prostaglandins, thromboxanes, prostacyclin, and their metabolites. $A d v$. Prostaglandin Thromboxane Res. 5:15-39.

13. Goldyne, M. E., R. K. Winkelman, and R. J. Ryan. 1973. Prostaglandin activity in human cutaneous inflammation. Detection by radioimmunoassay. Prostaglandins. 4:737-749.

14. Labarca, C., and K. Paigen. 1980. A simple, rapid, and sensitive DNA assay procedure. Anal. Biochem. 102:344-352.

15. Brotherton, A. F. A., D. E. Macfarlane, and J. C. Hoak. 1982. Prostacyclin biosynthesis in vascular endothelium is not inhibited by cyclic AMP. Studies with 3-isobutyl-1-methylxanthine and forskolin. Thromb. Res. 28:637-647.

16. Alhenc-Gelas, F., S. J. Tsai, K. S. Callahan, W. B. Campbell, and A. R. Johnson. 1982. Stimulation of prostaglandin formation by vasoactive mediators in cultured human endothelial cells. Prostaglandins. 24:723-742.

17. Gerritsen, M. E., and C. D. Cheli. 1983. Arachidonic acid and prostaglandin endoperoxide metabolism in isolated rabbit and coronary microvessels and isolated and cultivated coronary microvessel endothelial cells. J. Clin. Invest. 72:1658-1671.

18. Gecse, A., A. Ottlecz, Z. Mezei, G. Telegdy, F. Joo, E. Dux, and I. Karnushina. 1982. Prostacyclin and prostaglandin synthesis in isolated brain capillaries. Prostaglandins. 23:287-297.

19. Coughlin, S. R., M. A. Moskowitz, B. R. Zetter, H. N. Antoniades, and L. Levine. 1980. Platelet-dependent stimulation of prostacyclin synthesis by platelet-derived growth factor. Nature (Lond.) 288:600-602.

20. Moncada, S., and J. R. Vane. 1979. Arachidonic acid metabolites and the interactions between platelets and blood vessel walls. $N$. Engl. J. Med. 300:1142-1147.

21. Majerus, P. W. 1983. Arachidonate metabolism in vascular disorders. J. Clin. Invest. 72:1521-1525. 